\title{
Effect of the conceptus on quantitative and qualitative aspects of uterine secretion in pigs
}

\author{
S. M. M. Basha, F. W. Bazer* and R. M. Roberts \\ Department of Biochemistry and Molecular Biology and ${ }^{*}$ Department of Animal Science, \\ University of Florida, Gainesville, Florida 32610, U.S.A.
}

\begin{abstract}
Summary. Endometrial explants were removed from uteri of animals pregnant and pseudopregnant (5 mg oestradiol valerate on Days 11-15) for 60 days, from the gravid and non-gravid horns of unilaterally pregnant pigs at Day 60 of pregnancy and from non-pregnant animals at Day 12 of the oestrous cycle. The tissues were cultured in the presence of $\mathrm{L}-\left[{ }^{35} \mathrm{~S}\right]$ methionine for $24 \mathrm{~h}$, and the tissues and medium were then analysed separately by two-dimensional polyacrylamide gel electrophoresis. Radioactive polypeptides were identified by autoradiography of dried gels. Tissues from all except the cyclic animals released an identical group of polypeptides into the culture medium: the major radioactive products were 4 acidic polypeptides of low molecular weight and several basic proteins, which included the purple phosphatase uteroferrin, and lysozyme. In separate experiments explants from 3 unilaterally pregnant pigs were cultured with $\mathrm{L}-\left[{ }^{3} \mathrm{H}\right]$ leucine, and, on a fresh weight basis, the tissue from the non-gravid horn released significantly less radioactive macromolecular material into the medium in $24 \mathrm{~h}$ than did tissue from gravid horns. It therefore appears that although the nature of the secretion produced by the pregnant uterus is a consequence of maternal hormonal regulation alone, the tissue underlying a conceptus is quantitatively more active than that from unoccupied regions of a uterus.
\end{abstract}

\section{Introduction}

A number of unique proteins appear in the uterine secretions of pigs in the luteal phase of the oestrous cycle (Murray, Bazer, Wallace \& Warnick, 1972). These proteins are induced by progesterone since they are secreted by ovariectomized animals injected with progesterone, but not oestrogen (Knight, Bazer \& Wallace, 1973). They include lysozyme and leucine aminopeptidase (Roberts, Bazer, Baldwin \& Pollard, 1976) and the purple glycoprotein uteroferrin (Roberts \& Bazer, 1980). In addition, explants of endometrium from pregnant sows secrete uteroferrin in culture at a rate related to the stage of pregnancy of the donor animal (Basha, Bazer \& Roberts, 1979). Production of uteroferrin was maximal at Day 60 of pregnancy. The present experiments were to determine whether the presence of a conceptus influences the secretion of proteins by the uterus in either a qualitative or quantitative manner.

\section{Materials and Methods}

\section{Materials}

Acrylamide, $\mathrm{N}, \mathrm{N}, \mathrm{N}^{\prime} \mathrm{N}^{\prime}$-tetramethylethylenediamine and X-Omat RP film XRP-1 were products of Eastman-Kodak, Rochester, New York; Coomassie blue R-250 and N, ${ }^{\prime}$ diallyltartardiamide were from Bio-Rad Laboratories, Richmond, California; sodium dodecyl 
sulphate (SDS) (specially pure) was obtained from Gallard-Schlesinger Chemical Corp., Carle Place, New York; amino acids, dithiothreitol, protein standards, 2-mercaptoethanol and agarose were bought from Sigma Chemical Co., St Louis, Missouri; urea was from Pierce Chemicals, Rockford, Illinois; carboxymethyl cellulose was purchased from Whatman, Clifton, New Jersey; ampholines were from LKB, Uppsala, Sweden; L- $\left[{ }^{35} \mathrm{~S}\right]$ methionine (sp. act. $1270 \mathrm{Ci} / \mathrm{mmol}$ ) and $\mathrm{L}-\left[4,5-{ }^{3} \mathrm{H}\right]$ leucine (sp. act. $50 \mathrm{Ci} / \mathrm{mmol}$ ) were obtained from the Radiochemical Centre, Amersham, England; tissue culture supplies were purchased from Grand Island, New York. All inorganic chemicals used were reagent grade or better.

\section{Medium preparation}

Eagle's minimal essential medium was prepared with the omission of phenol red. It was supplemented with $5 \mathrm{mg}$ glucose/ml, antibiotics and antimycotics $(4 \%, \mathrm{v} / \mathrm{v}), 0.2$ units insulin $/ \mathrm{ml}, 1 \%(\mathrm{v} / \mathrm{v})$ of non-essential amino acids, and $5.2 \mu \mathrm{g} \mathrm{L}$-methionine $/ \mathrm{ml}$. The medium was filter-sterilized and stored at $3^{\circ} \mathrm{C}$ until used.

\section{Preparation of animals}

Gilts were observed for oestrus daily in the presence of intact boars and the day of onset of oestrus was designated Day 0 . Animals assigned to be unilaterally pregnant (Group 1) were mated at 12 and $24 \mathrm{~h}$ after detection of oestrus. On Day 18 conceptuses were flushed from one uterine horn with sterile $0.9 \%(\mathrm{w} / \mathrm{v}) \mathrm{NaCl}$. A ligature was placed around the pregnant uterine horn at a point immediately proximal to the external bifurcation of the uterus to isolate the pregnant and non-pregant uterine horns. Of 8 gilts so treated, 4 remained pregnant to Day 60 .

Pseudopregnancy (Group 2) was induced by injecting $5 \mathrm{mg}$ oestradiol valerate subcutaneously on Days 11 through 15 of the oestrous cycle as described by Frank, Bazer, Thatcher \& Wilcox (1977).

For comparative purposes, endometrium was obtained from non-pregnant gilts on Day 12 of the oestrous cycle (Group 3) and from a Day 60 bilaterally pregnant animal (Group 4). Day 12 was chosen since it represents a stage just before the major secretory phase of the oestrous cycle.

Routine surgical procedures and the method for obtaining uterine flushings have been described previously (Murray et al., 1972; Knight et al., 1973). Uterine flushings were obtained from sows in Groups 1 (non-gravid horn) and 2 on Day 60 after the onset of oestrus.

\section{Endometrial explants}

Preparation. Uteri were removed aseptically from the animals in all 4 groups (Day 60 for Groups 1, 2 and 4 and Day 12 for Group 3). The uterine horns were opened by longitudinal incisions along the antimesometrial surfaces to expose the endometrium. For the Group 4 animal and the pregnant horn of Group 1 sows the placentae were carefully stripped from the underlying endometrium before separating endometrium from myometrium, using scissors, under a sterile, laminar flow hood.

Incubation. Incubations were carried out according to the method of Basha et al. (1979) with some modifications. About $500 \mathrm{mg}$ endometrium were transferred into a sterile Petri dish and sliced into 2-4 mm pieces. After addition of $15 \mathrm{ml}$ medium each Petri dish was incubated at $37^{\circ} \mathrm{C}$ in an atmosphere of $95 \%$ air, $5 \% \mathrm{CO}_{2}$. After $1 \mathrm{~h} 50 \mu \mathrm{Ci} \mathrm{L}-\left[{ }^{35} \mathrm{~S}\right]$ methionine or, in some experiments, $5 \mu \mathrm{Ci} \mathrm{L}-\left[{ }^{3} \mathrm{H}\right]$ leucine were added to each dish which was then transferred to a special gas-tight chamber (Bellco Biological Glassware, Vineland, New Jersey). The chamber was flushed for $1 \mathrm{~min}$ with $50 \% \mathrm{O}_{2}-45 \% \mathrm{~N}_{2}-5 \% \mathrm{CO}_{2}$ (by volume) and incubated at $37^{\circ} \mathrm{C}$ in the dark on a rocking platform (6 cycles $/ \mathrm{min}$ ). This ensures that the cultures are alternately immersed in medium and then exposed directly to the gaseous phase. The technique has been 
used successfully for long-term culture of human bronchial tissue (Barrett, McDowell, Frank, Harris \& Trump, 1976). After $24 \mathrm{~h}$, incubations were terminated by chilling the incubation mixtures on ice and then centrifuged at $20000 \mathrm{~g}$ for $20 \mathrm{~min}$ to separate the tissue and medium. The medium was extensively dialysed against $10 \mathrm{~mm}$-Tris- $\mathrm{HCl}$ buffer $(\mathrm{pH} 8 \cdot 2)$ to remove low molecular weight compounds. The tissue and medium were presented as described below.

\section{Preparation of the samples}

The dialysed medium $(5 \mathrm{ml})$ was freeze dried and the dried material was dissolved in $1 \mathrm{ml} 5$ mM- $\mathrm{K}_{2} \mathrm{CO}_{3}$ containing $9.3 \mathrm{M}$-urea, $2 \%(\mathrm{v} / \mathrm{v})$ Nonidet P-40 and $0.5 \%(\mathrm{w} / \mathrm{v})$ dithiothreitol and used for two-dimensional polyacrylamide gel electrophoresis (PAGE). The tissue was suspended in $1 \mathrm{ml} 5 \mathrm{mM}-\mathrm{K}_{2} \mathrm{CO}_{3}$ and $9.3 \mathrm{M}$-urea and sonicated $(4 \times 15 \mathrm{sec}$ at $1 \mathrm{~min}$ intervals $)$ in an ice bath using a Bronwill Biosonic at $20-30 \%$ probe intensity. The sonicated material was made to $2 \%$ $(\mathrm{v} / \mathrm{v})$ with Nonidet P-40 and $0.5 \%(\mathrm{w} / \mathrm{v})$ with dithiothreitol and centrifuged at $20000 \mathrm{~g}$ for 30 $\min$ at $18^{\circ} \mathrm{C}$. The clear supernatant was used for PAGE analysis.

\section{Two-dimensional polyacrylamide gel electrophoresis}

This analysis was performed according to a modification of the method of O'Farrell (1975) as described by Horst \& Roberts (1979).

Isoelectric focussing. The acidic proteins of the tissue and medium were subjected to isoelectric focussing in the first dimension in $4 \%(\mathrm{w} / \mathrm{v})$ acrylamide gels containing $\mathrm{N}, \mathrm{N}^{\prime}$ diallyltartardiamide (as a cross-linker), 9.3 M-urea, 2\% (v/v) Nonidet P-40 and 2\% (v/v) ampholines $(3 \cdot 5-10,5-7$ and $9-11,50: 35: 15$ by volume respectively). The gels were then equilibrated for $10 \mathrm{~min}$ in $0.065 \mathrm{M}$-Tris- $\mathrm{HCl}$ buffer $(\mathrm{pH} 6.9)$ containing $1 \%(\mathrm{w} / \mathrm{v})$ SDS and $1 \%$ (v/v) 2-mercaptoethanol and subjected to electrophoresis in the second dimension in $10 \%$ acrylamide slab gels.

Non-equilibrium pH gradient electrophoresis. The basic proteins were focussed in the first dimension in $4 \%$ acrylamide gels prepared as previously described with a different ampholine composition. The method is based on that of O'Farrell, Goodman \& O'Farrell (1977). The ampholines used in this gel system were $9-11,8-9.5$ and $6-8 \quad(70: 20: 10$ by volume respectively). The protein migration was towards the cathode and the duration of electrofocussing was $3.5 \mathrm{~h}$. At the end of the run, gels were equilibrated for $10 \mathrm{~min}$ as described above and subjected to SDS-polyacrylamide slab gel electrophoresis in $10 \%$ acrylamide gels. The final position of polypeptides in the first dimension during this analysis is influenced by the volume of the sample applied to the gel and this is the reason for some inconsistencies in polypeptide position between experiments.

Second dimension electrophoresis. SDS-gel electrophoresis was performed according to the method of Laemmli (1970). The equilibrated tube gels after electrofocussing were overlayed on the $10 \%(\mathrm{w} / \mathrm{v})$ acrylamide slabs and electrophoresis performed towards the anode. The slabs were fixed and stained with Coomassie blue R-250. Slab gels were dried and autoradiographs were prepared from Kodak XRP 1 -X-ray film.

\section{Protein fractionation and ion-exchange chromatography}

The dialysed explant medium was passed through carboxymethyl cellulose column $(1.5 \times 5 \mathrm{~cm})$ and, after washing the column thoroughly, the bound protein was eluted with 10 mM-Tris- $\mathrm{HCl}$ buffer ( $\mathrm{pH} \mathrm{8.2)} \mathrm{containing} 0.5 \mathrm{M}-\mathrm{NaCl}$. The material passing through the column contained acidic and neutral proteins while the material bound to the cellulose contained the basic proteins. 
Acid phosphatase activity, radiochemical techniques and protein determination

The assay for acid phosphatase activity using $p$-nitrophenylphosphate as substrate has been described elsewhere (Schlosnagle, Sander, Bazer \& Roberts, 1976; Basha et al., 1979). One unit of activity is defined as the capacity to release $1 \mu \mathrm{mol}$ nitrophenol per min at $\mathrm{pH} 4.9$ in 0.1 M-acetate buffer. Radioactivity in samples was determined by standard procedures (Roberts \& Yuan, 1974). Total protein in the uterine flushings was measured colorimetrically by the method of Lowry, Rosebrough, Farr \& Randall (1951).

\section{Statistical analysis}

Analysis of variance was used to compare differences in protein concentration and total protein and acid phosphatase activity in uterine flushings from gilts in Groups 1 and 2. Differences in incorporation of $\mathrm{L}-\left[{ }^{3} \mathrm{H}\right]$ leucine into macromolecules by endometrium from gravid and non-gravid uterine horns were detected by analysing for gilt, uterine horn, gilt $\times$ uterine horn and replicate effects by analysis of variance (Steel \& Torrie, 1960).

\section{Results}

\section{Protein content and phosphatase activities of flushings}

All uterine flushings obtained from gilts in Groups 1 and 2 were a deep purple colour, indicating that they contained significant quantities of the progesterone-induced, purple glycoprotein (uteroferrin). Large amounts of protein were also recovered (Table 1). The amounts of total acid phosphatase and protein obtained, although variable, were not significantly different.

Table 1. Protein content and acid phosphatase activity per uterine horn in uterine flushings from pseudopregnant (Group 2) and the non-gravid horn of unilaterally pregnant (Group 1) gilts at Day 60 after onset of oestrus

\begin{tabular}{lcc}
\hline & $\begin{array}{c}\text { Group 2 } \\
\text { (pseudopregnant) }\end{array}$ & $\begin{array}{c}\text { Group 1 } \\
\text { (non-gravid horn) }\end{array}$ \\
\hline $\begin{array}{l}\text { No. of flushings } \\
\begin{array}{l}\text { Total recoverable } \\
\text { protein (m) }\end{array}\end{array}$ & 6 & 3 \\
$\begin{array}{l}\text { Total recoverable } \\
\text { acid phosphatase (units) }\end{array}$ & $271922 \cdot 7 \pm 869 \cdot 8$ & $1074 \cdot 8 \pm 602 \cdot 1$ \\
\hline
\end{tabular}

Values are mean \pm s.d.

Protein constituents of the uterine flushings

Two-dimensional gel electrophoresis of the proteins present in the flushings from Groups 1 and 2 gave very similar patterns (Plate 1). Several major acidic proteins with a molecular weight of $60000-90000$ were present, as well as 2 prominent protein spots of molecular weight around 21000 and pI positions of $6 \cdot 1$ and 6.3. Each of these 2 spots appeared to be composed of 2 polypeptides which were poorly resolved in this $10 \%$ polyacrylamide gel system.

Uteroferrin with an apparent molecular weight of about 37000 was clearly detected (Pl. 1, Figs 3 and 4). The identity of the 3 polypeptides of higher molecular weight located just above uteroferrin is at present unknown.

Lysozyme migrated as a single spot close to the tracking dye and ampholine front ( $\mathrm{Pl}$. 1, Figs 3 and 4$)$. The $10 \%(\mathrm{w} / \mathrm{v})$ polyacrylamide gels used failed to resolve polypeptides of molecular weight $<16000$. 


\section{Electrophoretic analysis of radioactive proteins}

Autoradiographs of the proteins present in the media of cultures of endometrial tissue from animals in all 4 groups are shown in Plate 2. The major radioactive component secreted in Groups 1 (both horns), 2 and 4 was an acidic molecule which had a molecular weight of around 21000 and an apparent pI of 6.3 (Pl. 2, Figs 5-8). This spot again appeared to be a doublet, consisting of two polypeptides of similar molecular weight, but identical isoelectric point. It co-migrated with one of the Coomassie blue positive doublets identified in the uterine flushings (P1. 1, Figs 1 and 2). Several other polypeptides containing much less ${ }^{35} \mathrm{~S}$ than the major spot were also present, including the second 21000 molecular weight doublet component obtained in uterine flushings.

The explants from Group 3 animals produced relatively less of these polypeptides (Pl. 2, Fig. 9). The major radioactive components were 2 polypeptides also present in the other groups of molecular weight 40500 and 42000 and isoelectric points of $5 \cdot 5$ and $5 \cdot 1$, respectively.

The major acidic proteins of higher molecular weight (those between 60000 and 40000 ) that were present in the flushings of all animals were not radioactive. These are probably not, therefore, synthesized by the uterus, but may represent proteins of serum origin.

When the basic proteins were examined by autoradiography of gels after non-equilibrium $\mathrm{pH}$ gradient electrophoresis, explants from animals in Groups 1 (both horns), 2 and 4 again released identical radioactive components into the medium (Pl. 3, Figs 11-14). These included the major Coomassie blue-stained polypeptides noted in uterine flushings (Pl. 1, Figs 3 and 4). In addition, several other radioactive polypeptides were detectable by autoradiography which did not appear to be major components of uterine flushings as judged by Coomassie blue staining.

The Group 3 explants again differed in that they did not secrete any of the 5 major basic proteins except lysozyme (P1. 3, Fig. 15).

That the polypeptides found in the medium were released selectively and did not merely represent proteins leaking from the tissues is illustrated in Pl. 2, Fig. 10 and Pl. 3, Fig. 16. Although the 5 basic and the 2 acidic polypeptides which were secreted into the medium could also be detected in trace amounts in the tissues themselves, several hundred other polypeptides, also radioactive, were not detected in the medium.

\section{Quantitative studies}

In these experiments the amounts of ${ }^{3} \mathrm{H}$ released in non-diffusible form, i.e. retained after dialysis, from explants of endometrial tissue from the gravid and non-gravid horns of 3 animals in Group 1 were compared. The incubations were for $24 \mathrm{~h}$ in the presence of $\mathrm{L}-\left[{ }^{3} \mathrm{H}\right]$ leucine $(5$

Table 2. Release (d.p.m./g tissue) of non-diffusible ${ }^{3} \mathrm{H}$ by explants of endometrium, cultured with $\mathrm{L}-\left[{ }^{3} \mathrm{H}\right]$ leucine, from the gravid and non-gravid horns of unilaterally pregnant gilts (Group 1)

\begin{tabular}{clcllc}
\hline & \multicolumn{2}{c}{ Gravid horn } & & \multicolumn{2}{c}{ Non-gravid horn } \\
\cline { 2 - 3 } Gilt & CMC-* & CMC+ + & & CMC - & CMC + \\
\hline 1 & $82671 \pm 7636$ & $35846 \pm 4487$ & & $48560 \pm 10166$ & $17399 \pm 5228$ \\
2 & $74209 \pm 9027$ & $31107 \pm 8856$ & & $58579 \pm 6485$ & $15934 \pm 3061$ \\
3 & $74605 \pm 11011$ & $25911 \pm 6110$ & $38316 \pm 2571$ & $10471 \pm 2850$ \\
Overall & $77162 \pm 9369$ & $30955 \pm 7417$ & & $45152 \pm 8182$ & $14601 \pm 4682$ \\
\hline
\end{tabular}

Values are mean \pm s.d. for 4 cultures.

CMC-, macromolecules not retained on carboxymethyl cellulose.

$\mathrm{CMC}+$, macromolecules retained on carboxymethyl cellulose.

* All values significantly different from those for the non-gravid horn, $P<0.05$.

$\dagger$ All values significantly different from those for the non-gravid horn, $P<0.01$. 


\section{PLATE 1}

Two-dimensional electrophoresis of the uterine flushings from a pseudopregnant sow (Figs 1 and 3 ) and from the non-gravid horn of a unilaterally pregnant sow (Figs 2 and 4). Gels were stained by Coomassie blue.

Figs 1 and 2. Separations by standard two-dimensional polyacrylamide gel electrophoresis. The arrows show the two doublets with isoelectric points of 6.3 and 6.1 (from left to right) which have molecular weights of around 21000 .

Figs 3 and 4. Analysis by non-equilibrium $\mathrm{pH}$ gradient electrophoresis. The arrows show the position of uteroferrin (u) which migrates as a streak consisting of several individual spots. Lysozyme (L) is also shown. The identification was established using highly purified uteroferrin. Secretions from 3 different animals from each treatment have been examined. Results were similar to the above in each comparison.

\section{PLATE 2}

Two-dimensional electrophoresis of the radioactive polypeptides secreted into the medium during culture of endometrial explants for $24 \mathrm{~h}$ in the presence of $\mathrm{L}-\left[{ }^{35} \mathrm{~S}\right]$ methionine. The polypeptides were separated by two-dimensional polyacrylamide electrophoresis, the gels were dried and radioactive spots were detected by autoradiography (exposure time 2 weeks). Each gel was run with $75000-150000$ d.p.m. of radioactive sample for Figs 5-9.

Fig. 5. Medium from culture of endometrium of a Day 60 pregnant sow (Group 4).

Fig. 6. Medium from culture of endometrium from a pseudopregnant sow (Group 2).

Figs 7 and 8. Medium from culture of endometrium from the gravid (Fig. 7) and non-gravid (Fig. 8) horns of a unilaterally pregnant sow (Day 60, Group 1).

Fig. 9. Medium from culture of endometrium from a non-pregnant sow (Day 12 of cycle, Group 3).

Fig. 10. Endometrial tissue from a Group 2 animal (pseudopregnant). About 250000 d.p.m. were placed on the gel.

\section{PLATE 3}

Two-dimensional electrophoresis of the basic radioactive polypeptides secreted into the medium during culture of endometrial explants for $24 \mathrm{~h}$ in the presence of $\mathrm{L}-\left[{ }^{35} \mathrm{~S}\right]$ methionine. The polypeptides were separated as in Pl. 1, Figs 3 and 4 . The amounts of radioactivity analysed were similar to those used in Plate 2, but the exposure time was about 5 weeks. The arrows indicate the positions of uteroferrin (u) and lysozyme (L). Experiments described in Plates 2 and 3 have been repeated at least 3 times with different animals.

Fig. 11. Medium from culture of endometrium of a Day 60 pregnant sow (Group 4).

Fig. 12. Medium from culture of endometrium of a pseudopregnant sow (Group 2).

Figs 13 and 14. Medium from culture of endometrium of the gravid (Fig. 13) and non-gravid (Fig. 14) horns of a unilaterally pregnant sow (Group 1).

Fig. 15. Medium from culture of endometrium of a non-pregnant sow (Day 12 of cycle, Group 3).

Fig. 16. Endometrial tissue from a Group 2 animal (pseudopregnant). 


\section{PLATE 1}
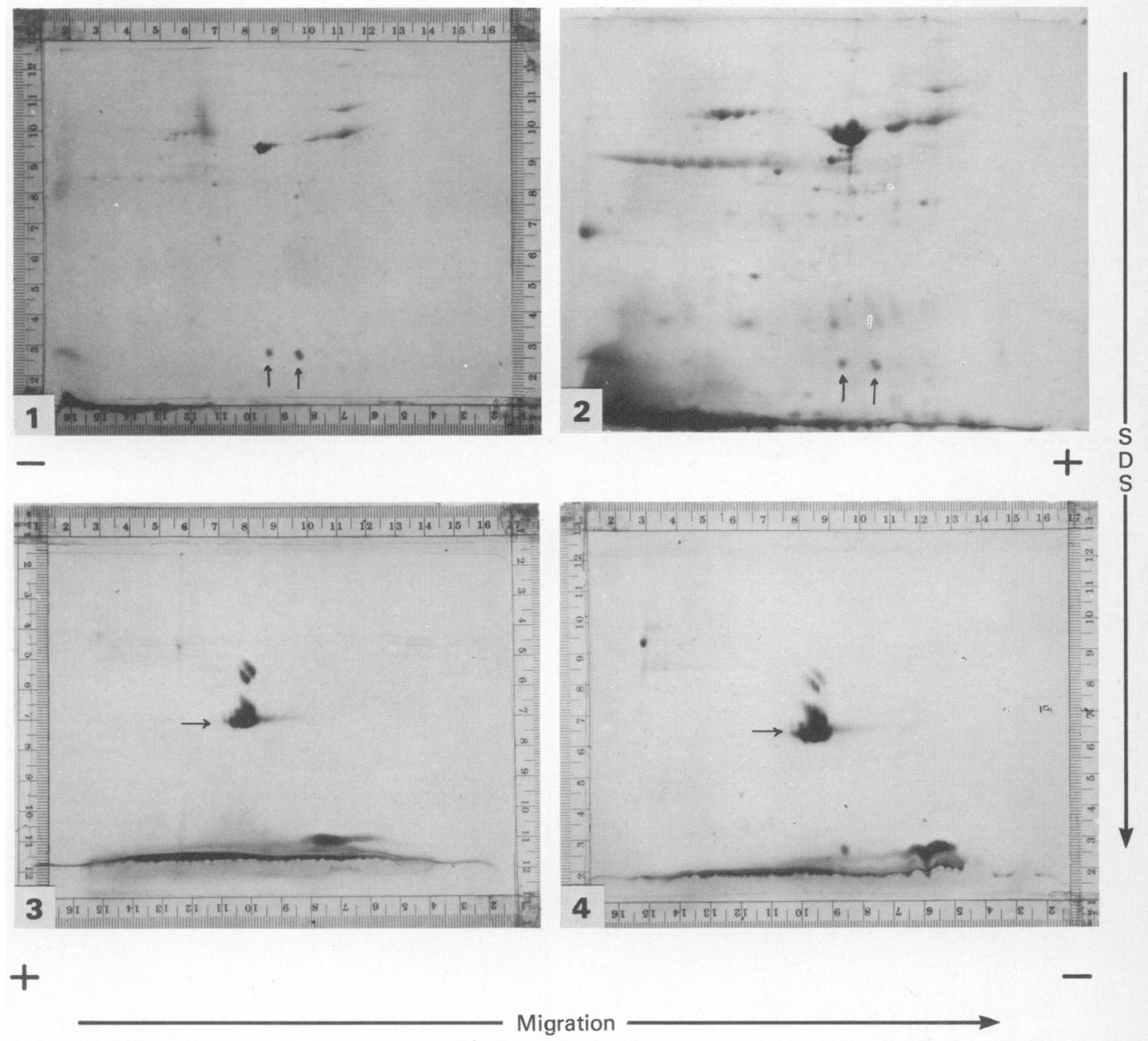
PLATE 2
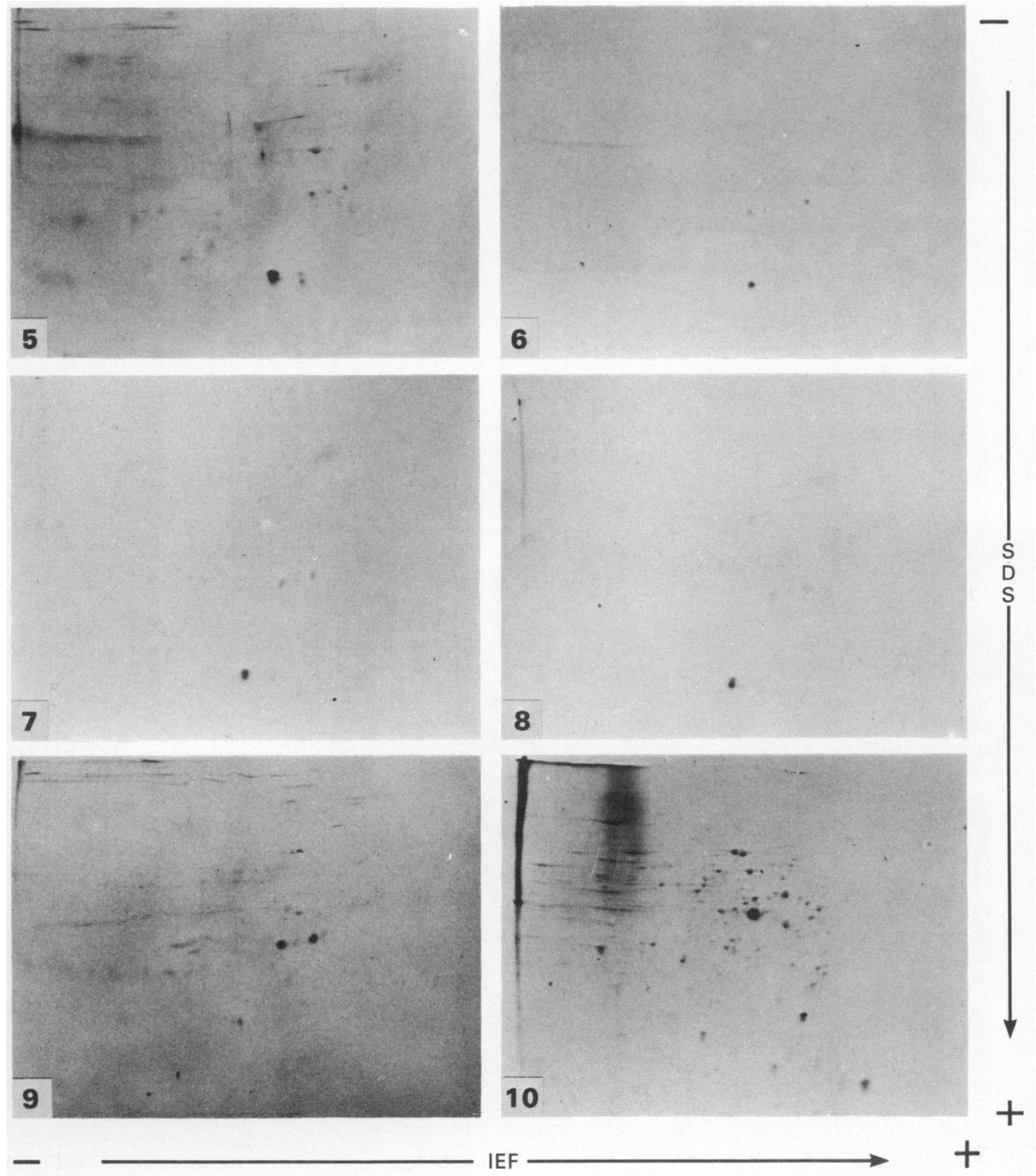


\section{PLATE 3}

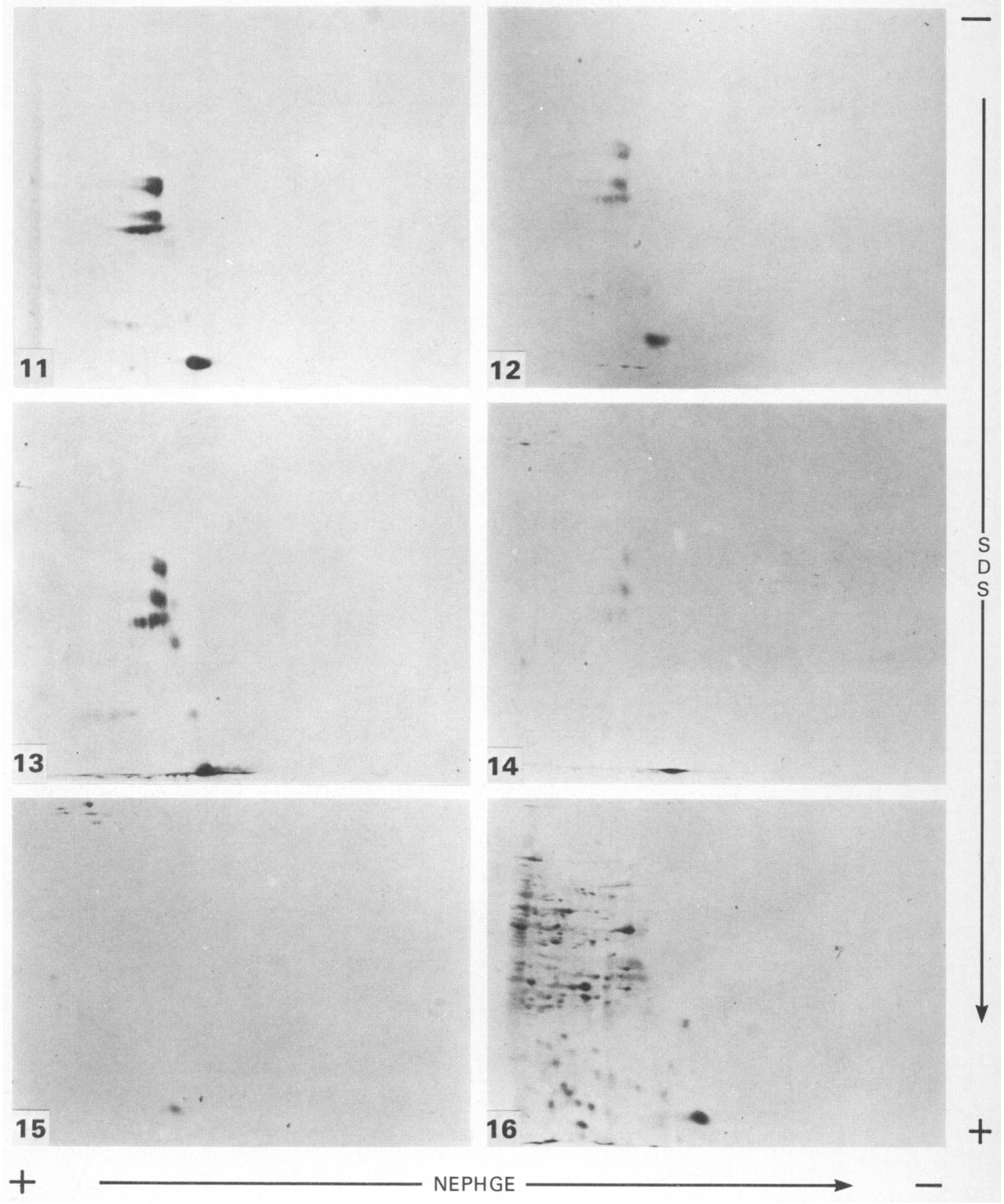


$\mu \mathrm{Ci} /$ dish) and 4 cultures were established from each uterine horn. The tissue from the gravid horn was synthetically more active than that from the non-gravid horn (Table 2). Analysis of variance indicated significant differences between gravid and non-gravid horns, but not between gilts. Endometrium from the gravid uterus secreted approximately twice as much radioactive protein when expressed on a fresh tissue weight basis. About $30 \%$ of this ${ }^{3} \mathrm{H}$ bound to carboxymethyl cellulose at $\mathrm{pH} 8.2$, thus indicating the presence of strongly basic proteins. Immunoprecipitation of radioactive uteroferrin from unfractionated medium using specific sheep antiserum (Basha et al., 1979) yielded a precipitate containing about $12 \%$ of the total radioactivity in both culture types, again suggesting that the proportion of uteroferrin secreted by endometrium from gravid and non-gravid horns is similar and that explanted tissue from the gravid horn releases about twice as much uteroferrin in $24 \mathrm{~h}$ as does that from the non-gravid horn.

\section{Discussion}

These experiments indicate that proteins secreted by endometrium from a pseudopregnant animal and from the gravid and non-gravid horns of unilaterally pregnant sows were qualitatively identical. Among these proteins were 4 acidic polypeptides of low molecular weight and several basic proteins which include lysozyme and the purple glycoprotein uteroferrin, all of which were synthesized by short-term cultured explants of endometrium from all groups but the cycling animals.

In addition to the qualitative similarities, acid phosphatase activity and total protein recovered from the uterine horns of pseudopregnant and unilaterally pregnant gilts were not significantly different. The values were also fairly similar to those measured in ovariectomized animals given daily doses of progesterone for up to 60 days (Basha, Bazer, Geisert \& Roberts, 1980; Schlosnagle, Bazer, Tsibris \& Roberts, 1974). The recoveries of both acid phosphatase and total saline-flushed protein reported here were highly variable and probably incomplete because (i) the flushing procedure was inefficient and probably failed to extract all protein from within the uterine glands, and (ii) considerable quantities of denatured protein were found in particulate form and discarded before assay for protein and acid phosphatase activity of the flushings. More recent experiments, however, have confirmed that no significant quantitative differences exist in protein recovered per horn between Group 1 and Group 2 animals, and that ligation of one horn of a pseudopregnant sow does not lead to improved yield of protein in that horn (Basha et al., 1980).

The acid phosphatase activity of the secretions is contributed almost entirely by uteroferrin (Bazer et al., 1975), a protein which has been postulated to have its function in iron transport to the conceptus during pregnancy (Basha et al., 1979). The uteroferrin seems to exist in multiple forms of distinct pI but similar molecular weight in all of the experimental groups in which it was recovered. This variability in pI may represent different degrees of post-translational modification or the transcription of several genes coding for uteroferrin, but did not appear to reflect treatment differences.

We conclude that at Day 60 of pregnancy the presence of conceptuses does not have a major influence on the qualitative nature of the uterine secretions of sows. The protein composition of the secretions appears therefore to be a consequence of the maternal hormone concentrations. Local modulating effects mediated by the conceptus cannot be ruled out, however, since tissue from the gravid horn was more active in secretion than that from the non-gravid horn. It is tempting to suggest that either steroid or polypeptide hormones produced by the conceptus might be involved, although little information is available concerning such maternal-fetal interactions in the pig. 
We thank Mr E. Mansfield and Mr W. Clark for technical and surgical assistance and Dr M. N. Horst for invaluable help with the two-dimensional electrophoretic procedures. The work was supported by grants HD 08560 and HD 10436 from the National Institutes of Health and U.S.D.A. Cooperative Agreement 12-14-7001-1119. Florida Agricultural Experiment Station Journal Series No. 1753.

\section{References}

Barrett, L.A., McDowell, E.M., Frank, A.L., Harris, C.C. \& Trump, B.F. (1976) Long term organ culture of human bronchial epithelium. Cancer Res. 36, $1003-1010$.

Basha, S.M.M., Bazer, F.W. \& Roberts, R.M. (1979) The secretion of a uterine specific purple phosphatase by cultured explants of porcine endometrium. Dependency upon the state of pregnancy of the donor animal. Biol. Reprod. 20, 431-441.

Basha, S.M.M., Bazer, F.W., Geisert, R.D. \& Roberts, R.M. (1980) Progesterone-induced uterine secretions in pigs. Recovery from pseudopregnant and unilaterally pregnant gilts. J. Anim. Sci. 50, 113-123.

Bazer, F.W., Chen, T.T., Knight, J.W., Schlosnagle, D.C., Baldwin, N.J. \& Roberts, R.M. (1975) Presence of a progesterone-induced, uterine specific, acid phosphatase in allantoic fluid of gilts. J. Anim. Sci. 41, 112-119.

Frank, M., Bazer, F.W., Thatcher, W.W. \& Wilcox, C.J. (1977) A study of prostaglandin F2 $\alpha$ as the luteolysin in swine. III. Effects of estradiol valerate on prostaglandin $F$, progestins, estrone and estradiol concentrations in the utero-ovarian vein of nonpregnant gilts. Prostaglandins 14, 1183-1 196.

Horst, M.N. \& Roberts, R.M. (1979) Analysis of polypeptide turnover rates in Chinese hamster ovary cell plasma membranes using two dimensional electrophoresis. J. biol. Chem. 254, 5000-5007.

Knight, J.W., Bazer, F.W. \& Wallace, H.D. (1973) Hormonal regulation of porcine uterine protein secretions. J. Anim. Sci. 36, 546-553.

Laemmli, U.K. (1970) Cleavage of structural proteins during the assembly of the head of bacteriophage $T_{4}$. Nature, Lond. 227, 680-685.

Lowry, O.H., Rosebrough, N.J., Farr, A.L. \& Randall, P.J. (1951) Protein measurement using the folin phenol reagent. J. biol. Chem. 193, 265-275.
Murray, F.A., Bazer, F.W., Wallace, H.D. \& Warnick, A.C. (1972) Quantitative and qualitative variation in the secretion of protein by the porcine uterus during the estrous cycle. Biol. Reprod. 7, 314-320.

O'Farrell, P.H. (1975) High resolution two dimensional electrophoresis of proteins. J. biol. Chem. 250, 4007-4021.

O'Farrell, P.Z., Goodman, H.M. \& O'Farrell, P.H. (1977) High resolution two dimensional electrophoresis of basic as well as acidic proteins. Cell 12, $1133-1142$.

Roberts, R.M. \& Bazer, F.W. (1980) The properties, function and hormonal control of synthesis of uteroferrin, the purple protein of the pig uterus. In Steroid Induced Proteins, pp. 133-149. Ed. M. Beato. Elsevier-North Holland, Amsterdam.

Roberts, R.M. \& Yuan, B.O.C. (1974) Chemical modification of the plasma membrane polypeptides of cultured mammalian cells as an aid to studying protein turnover. Biochemistry, N.Y. 13, 4846-4855.

Roberts, R.M., Bazer, F.W., Baldwin, N.J. \& Pollard, W.E. (1976) Induction of lysozyme and leucine aminopeptidase activities in the uterine flushings of pigs by progesterone. Archs Biochem. Biophys. 177, 499-507.

Schlosnagle, D.C., Bazer, F.W., Tsibris, J.C.M. \& Roberts, R.M. (1974) An iron-containing phosphatase induced by progesterone in the uterine fluids of pigs. J. biol. Chem. 249, 7574-7579.

Schlosnagle, D.C., Sander, E.G., Bazer, F.W. \& Roberts, R.M. (1976) The requirement of an essential thiol group and ferric iron for activity of the progesterone-induced porcine uterine purple phosphatase. J. biol. Chem. 251, 4680-4685.

Steel, R.G.D. \& Torrie, J.H. (1960) Principles and Procedures of Statistics. McGraw-Hill, New York.

Received 7 November 1979 